http://dx.doi.org/10.12775/szhf.2015.018

\title{
Neowitalistyczna koncepcja życia Piotra Lenartowicza
}

\begin{abstract}
1. Wstęp
W siedemnastym, osiemnastym, dziewiętnastym i początkach dwudziestego wieku wokół pytania o „istotę życia” toczył się ożywiony spór między przedstawicielami dwóch przeciwstawnych stanowisk: „mechanicyzmu” i „witalizmu”. Część trwającej kilka stuleci kontrowersji między mechanicyzmem a witalizmem dotyczyła zagadnienia stosunku między opisem przyczynowym i teleologicznym. Zagadnienie to podejmuje w swoim fundamentalnym dziele Krytyka wtadzy sązenia z 1790 r., Immanuel Kant. Filozof z Królewca, choć nie był witalistą w ścisłym tego słowa znaczeniu, to jednak podkreślał niezbędność metody teleologicznej w opisie pochodzenia, rozwoju i funkcji żyjącego organizmu.

Do rozstrzygnięć I. Kanta dotyczących relacji przyczynowość-celowość nawiązywali w swych publikacjach liczni polscy filozofowie, a wśród nich, niedawno zmarły filozof, jezuita Piotr Lenartowicz. W niniejszym artykule podejmiemy próbę wydobycia Kantowskich inspiracji dla Lenartowicza neowitalistycznej koncepcji życia.
\end{abstract}




\section{Spór o istotę życia między mechanicyzmem i witalizmem}

Spór wokół pytania o „istotę życia” między przedstawicielami dwóch przeciwstawnych stanowisk toczył się już od siedemnastego wieku. Kolejne pokolenia mechanicystów i witalistów modyfikowały swoje poglądy na naturę życia, czyniąc je coraz bardziej skomplikowanymi ${ }^{1}$.

\subsection{Mechanicyzm}

Idee mechanicystyczne głosili i rozwijali już starożytni materialiści, tacy jak np. Leucyp, Demokryt, Anaksagoras, Lukrecjusz². Za twórcę klasycznego mechanicyzmu uważa się jednak Kartezjusza. Według stworzonej przez niego mechanicystycznej koncepcji życia, organizm zwierzęcy jest niczym innym jak tylko maszyną ${ }^{3}$. Zwolennicy mechanicyzmu kartezjańskiego usiłowali sprowadzić wszelkie zjawiska życiowe do procesów mechanicznych ${ }^{4}$. Wśród obrońców i propagatorów doktryny mechanicystycznej znalazło się wielu znanych filozofów, jak np. Thomas Hobbes, Julien Lamettrie i Paul Holbach5 .

Skrajnym przedstawicielem mechanicyzmu w biologii był Jacques Loeb ${ }^{6}$. Jako uczeń Ernsta Macha był zwolennikiem reprezentowanego przez tego myśliciela kierunku, zwanego empiriokrytycyzmem ${ }^{7}$. Loeb reprezentował surowy krytycyzm i nie zgadzał się na jakiekolwiek wpływy metafizyki w analizach fenomenu życia. Postulował, aby wszelkie zjawiska życiowe traktować wyłącznie jako przejaw sił fizycznych i chemicznych ${ }^{8}$. W jego

${ }^{1}$ Por. D. L. Hull, The Philosophy of Biological Science, Prentice-Hall, Englewood Cliffs, New Jersey 1974, s. 127.

${ }^{2}$ Por. M. Heller, M. Lubański, S. Ślaga, Zagadnienia filozoficzne współczesnej nauki. Wstęp do filozofii przyrody, Wyd. ATK, Warszawa 1997, s. 331.

${ }^{3}$ Por. W. Kunicki-Goldfinger, Podstawy biologii. Od bakterii do człowieka, PWN, Warszawa 1980, s. 29.

${ }^{4}$ Por. tenże, Dziedzictwo i przyszłość. Rozważania nad biologiq molekularna, ewolucja i człowiekiem, PWN, Warszawa 1974, s. 28.

${ }^{5}$ Por. D. Favrholdt, Introduction, [w:] Niels Bohr. Collected Works. Vol. 10. Complementarity beyond Physics (1928-1962), red. D. Favrholdt, Elsevier, Amsterdam 1999, s. [3].

${ }^{6}$ Por. J. Nusbaum-Hilarowicz, Idea ewolucji w biologii, t. 1: Zarys dziejów ewolucjonizmu do końca XIX wieku, Państwowe Wydawnictwo Rolnicze i Leśne, Warszawa 1952, s. 764.

${ }^{7}$ Por. A. Mahrburg, Słowo wstępne, [w:] J. Loeb, Wstęp do fizjologii i psychologii porównawczej, przeł. Z. Szymanowski, Warszawa 1906, s. 9.

${ }^{8}$ Por. J. Loeb, Wstęp do fizjologii i psychologii porównawczej, s. 19. 
przekonaniu wszystkie zjawiska życiowe można ostatecznie sprowadzić do ruchów lub zmian zachodzących w koloidach9

Ostatecznie dla większości biologów stała się oczywista absurdalność mechanicystycznych wyjaśnień fenomenu życia ${ }^{10}$. Zajęli oni stanowisko agnostyczne, w myśl którego dostarczenie wyczerpującego opisu organizmów żywych przekracza możliwości mechaniki.

\subsection{Witalizm}

Podobnie jak mechanicyzm, witalizm ze swą wiarą w specyficzną siłę życiową ${ }^{11}$, która różni się w sposób zasadniczy od jakichkolwiek innych sił przyrody, jest bardzo starym stanowiskiem ${ }^{12}$. Źródeł witalistycznych koncepcji życia należy szukać już w poglądach Pitagorasa, Platona, a zdaniem niektórych także u Arystotelesa ${ }^{13}$. Witalizm w swej klasycznej formie był rozwijany i propagowany w XVIII w. we Francji przez członków szkoły Montpellier ${ }^{14}$. Członkowie tej szkoły kładli nacisk na istnienie swoistej zasady, siły życiowej, o charakterze pozaempirycznym, która jest odpowiedzialna za rozwój organizmu i procesy życiowe w nim zachodzące ${ }^{15}$. Podobną doktrynę rozwijali i głosili również m.in., Johann Baptista van Helmont, Christian Wolff, Johann Friedrich Blumenbach ${ }^{16}$.

Najbardziej znaną postacią witalizmu, odwołującą się do eksperymentów biologicznych, jest koncepcja niemieckiego embriologa Hansa Adolfa Eduarda Driescha ${ }^{17}$. Chcąc wykazać słuszność swej teorii, przedstawił trzy

\footnotetext{
${ }^{9}$ Por. tamże, s. 21.

${ }^{10}$ Por. E. Mayr, To jest biologia. Nauka o świecie ożywionym, przeł. J. Szacki, Prószyński i S-ka, Warszawa 2002, s. 23.

${ }^{11}$ Ową specyficzną siłę życiową określa się wyrażeniem „vis vitalis” (stąd nazwa „witalizm”). Zob. K. Petrusewicz, Mechanizm i witalizm a materializm dialektyczny, „Myśl Współczesna” 1951, nr 3/4, s. 397.

${ }^{12}$ Por. J. Nusbaum-Hilarowicz, Szlakami wiedzy. Szkice z zagadnień biologii współczesnej, Lwów 1921, s. 5.

${ }^{13}$ Por. M. Heller, M. Lubański, S. Ślaga, Zagadnienia filozoficzne współczesnej nauki, s. 333.

${ }^{14}$ Por. R. Zaniewski, Teorie o pochodzeniu i rozwoju życia a naturalizm chrześcijański, Katolicki Ośrodek Wydawniczy „Veritas”, Londyn 1953, s. 26.

${ }^{15}$ Por. M. Heller, M. Lubański, S. Ślaga, Zagadnienia filozoficzne współczesnej nauki, s. 333.

${ }^{16}$ Por. R. Zaniewski, Teorie o pochodzeniu i rozwoju życia a naturalizm chrześcijański, s. 26.

${ }^{17}$ Por. tamże, s. 26.
} 
dowody ${ }^{18}$. Dwa z nich są oparte na analizie zjawisk, związanych z procesem morfogenezy, natomiast trzeci nie jest dowodem ściśle biologicznym, a dotyczy sfery życia psychicznego. Driesch chciał wykazać, że u podstawy życia znajduje się coś z natury nieorganicznego, co nazwał „entelechią"19. W związku z tym przekonywał, że fenomenu życia nie można sprowadzić do procesów fizyko-chemicznych; życie posiada własną autonomię, rządzi się swoimi prawami. Nazwę „entelechia” zapożyczył od Arystotelesa. Swojej „entelechii” nie utożsamia jednak z „entelechią” Stagiryty. Według Driescha, „entelechii” nie należy utożsamiać z siłą, energią ${ }^{20}$ czy stałą własnością organizmu żywego, gdyż ma ona tylko punkty przejawiające swą aktywność w przestrzeni, ale sama się w niej nie znajduje. „Entelechia” nie jest też, jak podkreśla, równoznaczna z „przyczynowością” czy „substancją”21, ale jest do nich tylko podobna i wymagając istnienia jednej i drugiej, jest jednak czymś więcej niż one ${ }^{22}$. „Entelechia”, według poglądów tego badacza, jako czynnik regulujący, budujący, indywidualizujący, jest czymś ,,ponadindywidualnym", ,ponadosobowym”.

Witalizm blokował możliwości poznawania chemizmu żywej materii ${ }^{23}$. Przełomową datą był rok 1828, kiedy to udało się niemieckiemu chemikowi Friedrichowi Wöhlerowi otrzymać na drodze laboratoryjnej mocznik z tzw. cyjanianu amonowego ${ }^{24}$. Dotąd uważano, że mocznik może powstawać tylko w żywych ustrojach pod wpływem działania „siły życiowej”. Tym samym dla wielu stało się jasne, że nie ma zasadniczych różnic między strukturą związków organicznych wytworzonych w laboratorium a powstałych w organizmie. Jedne i drugie zbudowane są z atomów wchodzących w skład ich pierwiastków i podlegają tym samym prawom chemicznym.

${ }^{18}$ Por. B. Rutkiewicz, Współczesny antymechanizm biologiczny i podstawy finalizmu, Lublin 1929, s. 11.

${ }^{19}$ Por. tenże, Neowitalizm, „Biblioteka Warszawska” 1912, nr 1, s. 114.

${ }^{20}$ Zob. H. Driesch, Der Vitalismus als Geschichte und als Lehre, J. Barth, Leipzig 1905, s. 133-238 .

${ }^{21}$ Zob. tamże, s. 238-241.

${ }^{22}$ Por. B. Rutkiewicz, Neowitalizm, s. 115.

${ }^{23}$ Por. A. Jurand, Budowa żywej materii, „Wiedza Powszechna”, Warszawa 1957, s. 6-7.

${ }^{24}$ Por. tamże, s. 7. 


\section{Immanuela Kanta „filozofia tego, co organiczne”}

Część późniejszych kontrowersji między zwolennikami doktryny mechanicystycznej i witalistycznej dotyczyła problemu relacji między opisem przyczynowym i teleologicznym. Zagadnieniem tym zajął się Immanuel Kant w swoim dziele Krytyka władzy sądzenia. Podkreśla on niezbędność metody teleologicznej w opisie pochodzenia, rozwoju i funkcji żyjącego organizmu ${ }^{25}$.

Według tego filozofa, sądy wydawane o procesach życiowych jako celowych są obiektywne, a nie subiektywne, co oznacza, że celowość należy do samego organizmu ${ }^{26}$. Fenomen życia, w oczach Kanta, jest więc zasadą wewnętrzną, mocą substancji określającą działanie w sobie ${ }^{27}$.

Kant twierdzi, że sądy o procesach życiowych jako celowych są realne, materialne, a nie wyłącznie rozumowe, co oznacza, że procesom tym celowość faktycznie przypisuje pewien cel naturalny, jak np. samozachowanie ${ }^{28}$. Według niego, celowość taka jest nie tylko formalna i rozumowa, która odsłania się przed matematykiem, rozważającym związek figur geometrycznych, nie przypisując im przy tym żadnego celu.

Filozof z Królewca stoi na stanowisku, że sądy wydawane o procesach życiowych, są wreszcie wewnętrzne, a nie zewnętrzne w stosunku do przedmiotu, co oznacza, że celowość nie jest osadzona w przydatności do czegokolwiek poza przedmiotem, którego jest wewnętrzną właściwością ${ }^{29}$. Celowość biologiczna, będąc „właściwością” samego przedmiotu, różni się zasadniczo od celowości zewnętrznej i relatywnej, za sprawą której pewien przedmiot jest użyteczny dla człowieka, zwierząt czy roślin.

W biologicznych sądach teleologicznych Kant nie głosi istnienia immaterialnego czynnika, w postaci nieuchwytnej dla analiz fizyko-chemicznych siły witalnej o skutkach materialnych ${ }^{30}$. W ten sposób swym pojęciem celo-

\footnotetext{
${ }^{25}$ Por. D. Favrholdt, Introduction, [w:] Niels Bohr. Collected Works, Vol. 10, Complementarity beyond Physics (1928-1962), red. D. Favrholdt, Elsevier, Amsterdam 1999, s. [4].

${ }^{26}$ Por. I. Kant, Krytyka władzy sądzenia, przeł. J. Gałecki, PWN, Warszawa 1986, s. 313. Zob.

O. Höffe, Immanuel Kant, przeł. A. Kaniowski, PWN, Warszawa 1995, s. 276. Zob. I. Kant, Krytyka władzy sadzenia, przeł. J. Gałecki, PWN, Warszawa 1986, s. 313.

${ }^{27}$ Por. S. Zięba, Natura życia w aspekcie organizacji, „Nauka” 1998, nr 4, s. 38.

${ }^{28}$ Por. I. Kant, Krytyka władzy sądzenia, s. 317. Zob. O. Höffe, Immanuel Kant, s. 276.

${ }^{29}$ Por. I. Kant, Krytyka władzy sązenia, s. 321-322. Zob. O. Höffe, Immanuel Kant, s. 276.

${ }^{30}$ Por. O. Höffe, Immanuel Kant, s. 276.
} 
wości biologicznej zdecydowanie odrzuca on witalistyczne sposoby wyjaśnienia fenomenu życia.

W przekonaniu Kanta, sądy teleologiczne o obiektywnej, realnej i wewnętrznej celowości można wydawać tylko wówczas, gdy nie jest możliwe dostateczne zrozumienie pewnych procesów biologicznych na podstawie wyjaśnień czysto przyczynowych ${ }^{31}$. Uważa on bowiem, że ,[...] pewna rzecz istnieje jako cel naturalny, jeśli jest (choć w dwojakim znaczeniu) przyczyną i skutkiem samej siebie" ${ }^{\prime 2}$. Dlatego też według tego myśliciela w obszarze tego, co organiczne każde liniowe myślenie przyczynowe napotyka granicę. Stoi on na stanowisku, że na żywy organizm trzeba więc patrzeć jako na całość zorganizowaną. Jego organizacja nie jest skutkiem żadnej zewnętrznej przyczyny $^{33}$.

W kontekście stwierdzenia, że ,[...] pewna rzecz istnieje jako cel naturalny, jeśli jest [...] przyczyną i skutkiem samej siebie [...]"34, Kant rozważa wzajemność skutku i przyczyny ${ }^{35}$. Aby zilustrować te wzajemne relacje zachodzące między skutkiem i przyczyną, których wyrazem jest samoorganizacja występująca $\mathrm{w}$ organizmie żywym, posługuje się on przykładem drzewa $^{36}$. W wyniku rozmnażania drzewa określonego rodzaju otrzymujemy inne drzewo tego samego rodzaju ${ }^{37}$. W konsekwencji dochodzimy do stwierdzenia, że wspomniane drzewo, jako rodzaj, jest równocześnie i przyczyną, i skutkiem. Wzajemność skutku i przyczyny znajduje swój wyraz także w procesie wzrostu rośliny, kiedy to przerabia ona dostępne surowce, po czym je przyswaja, by nadać im w efekcie pewną swoistą jakość. Tak więc drzewo niejako samo się organizuje, tworzy, zachowując się jak indywiduum.

W swoich rozważaniach, poświęconych problematyce życia, Kant bardzo zdecydowanie przeciwstawia się doktrynie mechanicystycznej. W kontekście życia podejmuje on zagadnienia samoorganizacji oraz wzajemności skutku i przyczyny, właśnie w tym celu, aby wyraźnie zaprotestować przeciwko wszelkim próbom utożsamiania organizmu żywego z zegarem, który jest wzorcowym przykładem procesów czysto mechanicznych. Według nie-

${ }^{31}$ Por. O. Höffe, Immanuel Kant, s. 276.

${ }^{32}$ I. Kant, Krytyka władzy sądzenia, s. 328.

${ }^{33}$ Por. I. Kant, Krytyka władzy sądzenia, s. 332. Zob. O. Höffe, Immanuel Kant, s. 277.

${ }^{34}$ I. Kant, Krytyka władzy sadzenia, s. 328.

${ }^{35}$ Por. O. Höffe, Immanuel Kant, s. 277.

${ }^{36}$ Por. I. Kant, Krytyka władzy sądzenia, s. 328-330.

${ }^{37}$ Por. O. Höffe, Immanuel Kant, s. 277. 
go tego typu próby są bezpodstawne ${ }^{38}$. To wszystko, czego brakuje zegarowi, możemy znaleźć w organizmie żywym. Dlatego też stwierdza:

Istota uorganizowana jest więc nie tylko maszyną - ta bowiem zawiera w sobie siłę li tylko poruszającą - lecz posiada w sobie siłę kształtującą, i to taką, jakiej udziela materiom, które są jej pozbawione (organizuje je), a to znaczy, że posiada w sobie twórczą siłę rozrodczą, której nie można wytłumaczyć samą tylko zdolnością wprawiania w ruch (mechanizm) ${ }^{39}$.

Kant rozważa także problem dwóch sposobów wyjaśniania natury życia, a mianowicie mechanistycznego i teleologicznego ${ }^{40}$. U tego myśliciela problem ten przyjmuje postać antynomii: albo ,[...] wszelkie wytwarzanie rzeczy materialnych i ich form musi być uważane za możliwe podług li tylko mechanicznych praw [...]", albo że „,...] niektóre wytwory materialnej przyrody nie mogą być uważane za możliwe podług li tylko mechanicznych praw (wydanie o nich sądu wymaga zupełnie innego prawa przyczynowości, a mianowicie prawa przyczyn celowych)" ${ }^{\prime 1}$. Ta antynomia jest jednak, według niego, możliwa do usunięcia ${ }^{42}$. Jego zdaniem pryncypia mechanicyzmu i teleologii wyrażają dwa sposoby myślenia, które choć są niewspółmierne, to jednak obydwa niezbędne, jeżeli mamy dotrzeć i badać naturę życia ${ }^{43}$. Są one komplementarne w rozumieniu tego słowa przez Nielsa Bohra. Tylko wtedy bowiem organizm będzie pojmowany jako uorganizowany twór przyrody, ,[...] w którym wszystko jest wzajemnie celem i środkiem. Nic nie jest w nim nadaremne, bezcelowe i nic nie może być przypisane ślepemu mechanizmowi przyrody" 4 .

Zdaniem Michaela Ruse'a Kant, zaprzeczając, że można udzielić czysto fizycznego wyjaśnienia fenomenu życia, sytuuje się tym samym po stronie witalizmu ${ }^{45}$. Choć nie zgadzamy się z tą uwagą amerykańskiego filozofa, jednak trzeba przyznać, że poglądy Kanta na naturę życia jednoznacznie wpisują się w gorącą debatę mechanicyzm-witalizm, i są wyrazem poszu-

\footnotetext{
${ }^{38}$ Por. I. Kant, Krytyka władzy sądzenia, s. 333.

39 Tamże, s. 333-334.

${ }^{40}$ Por. O. Höffe, Immanuel Kant, s. 278.

${ }^{41}$ I. Kant, Krytyka władzy sądzenia, s. 353-354.

${ }^{42}$ Por. O. Höffe, Immanuel Kant, s. 278.

${ }^{43}$ Por. D. Favrholdt, Introduction, s. [4].

${ }^{44}$ I. Kant, Krytyka władzy sq̨dzenia, s. 336.

${ }^{45}$ Por. M. Ruse, Review: A. Rosenberg, Darwinian Reductionism. Or, How to Stop Worrying and Love Molecular Biology, „The Philosophical Quarterly” 2010, nr 60, s. 206.
} 
kiwania odpowiedzi na fundamentalne pytanie, wciąż będące nierozwiązaną zagadką.

\section{Piotra Lenartowicza neowitalistyczna koncepcja życia}

Piotr Lenartowicz nie ukrywa swoich inklinacji witalistycznych. Wprost przyznaje się do fascynacji eksperymentami H. Driescha i R. Spemanna. Pisze:

Zacząłem gromadzić materiał dotyczący głównie biologii rozwoju. Zorientowałem się, że doświadczenia H. Driescha i R. Spemanna, cała kwestia, która dzisiaj jest nazwana teorią klonowania, ma kluczowe znaczenie dla teorii życia biologicznego ${ }^{46}$.

Według Lenartowicza, czynnikiem, który współcześnie zastępuje pojęcie siły życiowej, jest pojęcie genomu ${ }^{47}$; w monizmie materialistycznym utożsamiane $\mathrm{z}$ garniturem chromosomów ${ }^{48}$. Polski filozof nie zgadza się jednak $\mathrm{z}$ takim zawłaszczaniem tego pojęcia przez doktrynę materialistyczną. Dostrzega konieczność wyraźnego odróżnienia pojęcia genomu strukturalnego od pojęcia genomu dynamicznego. Genom strukturalny to chromosomy, które są ograniczone w swych możliwościach, natomiast genom dynamiczny, o niematerialnym charakterze, decyduje o całościowym rozwoju konkretnego żywego organizmu ${ }^{49}$. Genom dynamiczny nie posiada, jak twierdzi, wymiaru materialnego, tzn. nie jest zależny od parametrów przestrzeni i cza$\mathrm{su}^{50}$. Pisze:

[...] minimalny układ funkcjonalny, który składa się z przynajmniej dwóch części [...] żeby powstał [...] to musi być - liczbowo - znacznie więcej elementów sprawczych, które by przeprowadziły surowiec materii mineralnej w stan dopasowania tych dwóch części do siebie z możliwością ekonomicznego przekazu energii. Ten schemat musi być ściśle kontrolowany w przestrzeni i ściśle

${ }^{46}$ Z. Wróblewski, Rozmowa z Piotrem Lenartowiczem SJ, [w:] Vivere et Intelligere. Wybrane prace Piotra Lenartowicza SJ wydane z okazji 75-lecia jego urodzin, red. J. Koszteyn, WAM, Kraków 2009, s. 34.

${ }^{47}$ Por. tamże.

${ }^{48}$ Por. tamże, s. 44. Zob. P. Lenartowicz, Sens i zakres pojęcia informacji genetycznej, [w:] Vivere et Intelligere, s. 135-136.

${ }^{49}$ Por. Z. Wróblewski, Rozmowa z Piotrem Lenartowiczem, s. 44-45.

${ }^{50}$ Por. tamże, s. 45. 
kontrolowany w czasie. Czyli wymaga kontroli ponadczasowej i ponadprzestrzennej ${ }^{51}$.

Podobny postulat wysunął H. Driesch. Zdaniem Lenartowicza, potencjał materii nieożywionej nie daje możliwości wydobycia czynnika, który odgrywałby rolę genomu. Czynnik ten działa bowiem, jak podkreśla, we wszystkich poziomach równocześnie, od molekularnego po anatomiczny. Całość nie dotyczy, jak twierdzi, struktur atomowych lub cząsteczkowych ${ }^{52}$. Ma on na myśli całość dynamiki tworzącej określony ekotyp, np. takiego, a nie innego egzemplarza rośliny. Genom, podobnie jak dusza, dla Lenartowicza, nie jest jakimś materiałem, ale tym, co kształtuje materiał, posługuje się materiałem.

Przyznanie genomowi niematerialnego charakteru nie zamyka, jak twierdzi Lenartowicz, drogi do jego wykorzystania w praktyce badawczej. Pisze:

Gdyby zamiast monistycznego fragmentaryzmu uznać konkretną formę żywą za niepodzielny pęczek potencjalności, to rolą biologa byłoby badanie zakresu tej potencjalności. [...] Biolog powinien badać jak roślina zareaguje na zmianę składu chemicznego atmosfery, na zmianę w barwie oświetlenia, na zmianę dostępnego pokarmu. W ten sposób biolog mógłby stopniowo uzyskiwać coraz pełniejsze pojęcie możliwości rozwojowych obecnych i działających w konkretnej formie żywej. Taka postawa wymaga traktowania formy żywej jako całości i wymaga dopuszczenia myśli, że w zmienionych warunkach forma żywa zachowuje się (w pewnych granicach) jako istota działająca racjonalnie ${ }^{53}$.

Wobec postulatów wysuwanych przez witalistów podnoszony jest zarzut, że są metafizyczne, a nie naukowe. Lenartowicz, broniąc swojego stanowiska, odpowiada na powyższy zarzut: „Oczywiście jądrem całego sporu są zjawiska integrującej epigenezy cyklu życiowego, adaptacje fenotypowe, regeneracje. $\mathrm{W}$ moim przekonaniu monizm nie jest w stanie tych zjawisk poprawnie opisać ani nie jest w stanie ich zrozumieć" ${ }^{54}$. Proponowana przez Lenartowicza koncepcja witalistyczna ma usuwać wszystkie powyższe ograniczenia. Pisze:

\footnotetext{
${ }^{51}$ Tamże, s. 45.

${ }^{52}$ Por. tamże, s. 46.

${ }^{53}$ Tamże, s. 47.

${ }^{54}$ Tamże, s. 48.
} 
Jeżeli organizm w perfekcyjny sposób reperuje swoje uszkodzone narządy, to przeszedł przez test inteligencji [...]. Jeżeli ktoś teraz powie, że pojęcie inteligencji tak samo da się wytłumaczyć przy pomocy materiału wziętego z materii mineralnej, jak każde inne pojęcie fizyczno-chemiczne, to dalszy dialog wydaje się już niemożliwy ${ }^{55}$.

Inny zarzut wysuwany pod adresem witalizmu jest taki, że pozostaje w konflikcie z prawami fizyki i chemii. Odpowiadając, polski filozof wyjaśnia, że jego pojęcie genomu dynamicznego nie wprowadza żadnej nowej możliwości, ale tylko ogranicza możliwości materiału mineralnego. Pisze:

Witalizm wskazuje na to, że w dynamice biologicznej zachodzi kolosalne ograniczenie działania praw fizyki oraz chemii. Analogicznie podczas konstruowania mechanizmu zegara nie zachodzi przezwyciężanie praw fizyki i chemii, ale ich wykorzystywanie, przy równoczesnym ograniczeniu ich działania ${ }^{56}$.

Jaka jest geneza genomu dynamicznego? Odpowiedź Lenartowicza nie pozostawia wątpliwości: został stworzony (z niczego) przez Boga ${ }^{57}$. Czynnik ograniczający nie jest materią mineralną, ani jej pochodną. Jest jednak formą „organiczną", i jako taki jest wewnętrznie zależny w swym działaniu od narzędzi materialnych ${ }^{58}$. Żeby doszło do stworzenia formy żywej, musiały być, zdaniem Lenartowicza, zagwarantowane następujące warunki: musiało być przygotowane pewne minimalne wyposażenie w elementarne narzędzia (np. enzymy, nukleotydy) oraz w pewien zapas materiału strukturalnego i energetycznego; zaszyfrowanie cząsteczek DNA, które by pasowały do konkretnego typu substancji, która ma powstać; stworzenie genomu dynamicznego, który by działał, wykorzystując wspomniane narzędzia materi a ln e. Akt stwórczy obejmuje tylko zaistnienie czynnika ograniczającego.

\footnotetext{
${ }^{55}$ Tamże.

56 Tamże, s. 50.

${ }^{57}$ Por. tamże, s. 51.

${ }^{58}$ Por. tamże. Zob. P. Lenartowicz, Trzy koncepcje dynamiki biologicznej: arystotelesowska, neo-darwinowska, inteligentnego projektu, [w:] Vivere et Intelligere, s. 289-293.
} 


\section{Piotra Lenartowicza recepcja I. Kanta „filozofii tego, co organiczne"}

Poglądy I. Kanta wywarły duży wpływ na witalistów, zwłaszcza w Niemczech $^{59}$. Wpływ ten można zauważyć przede wszystkim w pracach H. Driescha, a także późniejszych witalistów. Piotr Lenartowicz, nawiązując do dziedzictwa witalistów, w szczególności Driescha, opracowując własną, nowoczesną wersję witalistycznej koncepcji życia, nawiązał także do spuścizny I. Kanta.

Właśnie za sprawą I. Kanta kluczowe pojęcie filozofii, jakim jest całość, stanowi przedmiot ożywionej dyskusji ${ }^{60}$. Zainspirowany bez wątpienia przez filozofa z Królewca, dokonał szczegółowej analizy tego pojęcia i roli, jaką ono odegrało w rozwoju konkretnej dyscypliny przyrodniczej, a mianowicie embriologii.

Lenartowicz swoiście pojmuje samą filozofię. Dla niego, filozofia to szukanie całości i badanie całości jako całości ${ }^{61}$. Pojęcie „całości” to nie to samo co ,wszystkość”. Pisze:

Odrzucałbym 'wszystkoizm' aprioryczny i godziłbym się z tym, że być może rzeczywistość składa się z pewnych pakietów, czy z pewnych elementów, które są ze sobą absolutnie niekompatybilne ${ }^{62}$.

W związku z tym uważam - pisze w innym miejscu Lenartowicz - że biolog, który się zajmuje kretami, albo mrówkami, albo pszczołami, w większym stopniu jest filozofem niż filozof, który czyta o myślach rozmaitych filozofów na temat 'rzeczywistości', która w moim przekonaniu nie wiadomo czy jest całością. Filozofowie interesują się 'wszystkością), ale ja nie uważam 'wszystkości' za całośćc ${ }^{3}$.

\footnotetext{
${ }^{59}$ Por. E. Mayr, To jest biologia, s. 26. Zob. W. E. Carlo, Reductionism and Emergence: Mechanism and Vitalism Revisited, „Proceedings and Addresses of the American Philosophical Association" 1966, nr 40, s. 101.

${ }^{60}$ Por. P. Lenartowicz, Pojęcie całości i przyczyny w dziejach embriologii, [w:] Vivere et Intelligere, s. 61.

${ }^{61}$ Por. Z. Wróblewski, Rozmowa z Piotrem Lenartowiczem SJ, s. 39.

${ }^{62}$ Tamże, s. 31.

${ }^{63}$ Tamże, s. 39.
} 
Lenartowicz swoje analizy ogranicza do substancji żywej ${ }^{64}$. Nie zajmuje się bytem w ogóle (ens ut tale), gdyż jest zbyt abstrakcyjny ${ }^{65}$. Dostrzega wielowarstwową strukturę $\mathrm{w}$ bycie ożywionym ${ }^{66}$. Jest $\mathrm{w}$ nim $\mathrm{w}$ arstwa e pifen omenalna, czyli to, co widzimy, a więc wszystkie zjawiska powierzchniowe. Pod nią są tzw. akcydensy nieistotowe, np. różnica temperatur ciała między jaszczurką, która wygrzewa się na słońcu i tą, która siedzi w miejscu zacienionym. Akcydensy is to towe natomiast to w przypadku jaszczurki np. to, że w danej chwili ma ona taką, a nie inną masę czy długość. Głębszą „warstwę ontyczną” stanowią tzw. atrybuty. W przypadku np. żaby między stadium kijanki i dorosłym osobnikiem występuje zmiana atrybutu lokomocji i atrybutu oddychania. Lenartowicz podkreśla, że ani akcydensy, ani ich pełny repertuar nie są całościami. To substancja jest całością. Substancję można obserwować nie w jednej wybranej, ale w wielu skalach przestrzennych, i nie w jednym wybranym, ale w wielu przedziałach czasowych. Lenartowicz zakłada, że istnieją pewne nieciągłości w opisie cech osobnika, co jest przejawem wyraźnej niezgodności jego koncepcji bytu żywego z pewnymi kluczowymi postulatami darwinizmu. Najbardziej oczywisty przykład całości to osobnik jako konkretny byt biologiczny ${ }^{67}$.

Ważnym elementem dokonującej się na naszych oczach „rewolucji” w biologii jest stopniowe zastępowanie panującej do tej pory anatomiczno-fizjologicznej definicji żywego organizmu nową, rozwojowo-dynamiczną definicją ${ }^{68}$. Anatomiczno-fizjologiczna definicja organizmu była bazą dla spekulacji, w których stawiano znak równości między życiem a strukturami biochemicznymi lub komórkowymi. Fenomen życia identyfikowano wtedy z procesem autostabilizującym (homeostat), czyli ze stanem równowagi dynamicznej odpornej na zakłócenia równowagi środowiska ${ }^{69}$. Chociaż organizm rzeczywiście posiada cechy autostabilizacji, nie stanowią one jednak całościowego i samodzielnego aspektu jego dynamiki, a jedynie aspekt fragmentaryczny i niesamodzielny.

\footnotetext{
${ }^{64}$ Por. tamże, s. 43.

${ }^{65}$ Por. tamże, s. 42.

${ }^{66}$ Por. tamże, s. 43. Zob. J. Koszteyn, P. Lenartowicz, Struktura bytu żywego w arystotelizmie, [w:] Vivere et Intelligere, s. 358-364.

${ }^{67}$ Por. R. Darowski, Profesor Piotr Lenartowicz SJ, s. 12.

${ }^{68}$ Por. P. Lenartowicz, Pojęcie całości i przyczyny w dziejach embriologii, [w:] Vivere et Intelligere, s. 62.

${ }^{69}$ Por. tamże, s. 63.
} 
W koncepcji Lenartowicza pojawiają się tzw. nieredukowalne cechy opisowe osobnika. Wymienia on osiem takich cech:

Cechy identyfikacji osobniczej (np. linie papilarne, grupa krwi),

Cechy identyfikacji rasowej,

Cechy os obowości (np. „osobowość” u człowieka),

Cechy traumatyczne osobnicze (np. okaleczenia),

Cechy traumatyczne dziedziczne (defekty w strukturze czy funkcji pojawiające się w następnych pokoleniach),

Cechy adaptacyjne ilościowe (np. gęstość futra),

Cechy adaptacyjne funkcjonalne (np. przepoczwarzanie się gąsienicy w postać motyla),

Cechy istotowe (np. to, co sprawia, że rozpoznajemy kota w rysiu $)^{70}$.

Pojęcie postaci dojrzałej w koncepcji Lenartowicza ustąpiło miejsca pojęciu cyklu życiowego ${ }^{71}$. Organizmem żywym jest więc, jak podkreśla polski filozof, cykl życiowy każdego osobnika, a nie ten, czy inny etap życia, który jest tylko jego częścią ${ }^{72}$. Wszystkie cykle życiowe powiązane są w linie pokoleń $^{73}$. Dla Lenartowicza, cykl życiowy jest więc minimalną całością biologiczną ${ }^{74}$.

Ściśle z pojęciem całościowości łączy się pojęcie celowości. Poszukiwanie celowości w przyrodzie ożywionej było jednym z kluczowych tematów podejmowanych w refleksji przez I. Kanta. P. Lenartowicz, zainspirowany Kantem, także koncentruje się na tej ważnej dla filozofii biologii kwestii. Ważnym powodem, by na nowo zając się tym tematem, jest, jak sam podkreśla, okoliczność, że biologia od prawie dwustu lat tkwi w epoce antyteleologizmu (bezcelowości) ${ }^{75}$. Ten fakt skłania go do refleksji. Celowość w tej epoce dostrzega się jedynie w obszarze refleksyjnej, świadomej działalności człowieka ${ }^{76}$. Przyczyną tego stanu rzeczy jest, zdaniem Lenartowicza, „, [...]

\footnotetext{
${ }^{70}$ Por. J. Koszteyn, P. Lenartowicz, Integracja dynamiki biologicznej a drzewa rodowodowe istot żywch, [w:] Vivere et Intelligere, s. 747-760.

${ }^{71}$ Por. P. Lenartowicz, Pojęcie całości i przyczyny w dziejach embriologii, s. 62.

${ }^{72}$ Por. tenże, Mitologia programu genetycznego DNA, w: Vivere et Intelligere, s. 103.

${ }^{73}$ Por. R. Darowski, Profesor Piotr Lenartowicz SJ, s. 12.

${ }^{74}$ Por. Z. Wróblewski, Rozmowa z Piotrem Lenartowiczem SJ, s. 34.

${ }^{75}$ Por. P. Lenartowicz, Celowość dynamiki biologicznej a bezkierunkowość w ewolucjonizmie darwinowskim, [w:] Vivere et Intelligere, s. 337.

${ }^{76}$ Por. tamże, s. 338.
} 
dogmatyczny charakter teorii ewolucji darwinowskiej”, zgodnie z którym wszelkie inne niż świadome formy dynamiki biologicznej są uważane za skutek całkowicie bezcelowych chaotycznych oddziaływań ${ }^{77}$. Sednem programu biologii antyteleologicznej, jest, jak podkreśla polski filozof, przekonanie, że wszelkie formy żywe powstały dzięki bezkierunkowej selekcji naturalnej, bezkierunkowym mutacjom i bezkierunkowej dynamice materii nieożywionej ${ }^{78}$.

Lenartowicz protestuje przeciwko takiemu, jak twierdzi, zafałszowanemu i mocno zawężonemu podejściu do problemów biologicznych. „Chaos, przypadek, bezkierunkowość, itd. - pisze Lenartowicz - pojawia się w stosunkowo bardzo ograniczonym wycinku współczesnej biologii. Przede wszystkim tam, gdzie mowa o (hipotetycznych) początkach życia, o ewolucji życia, o specjacji $[\ldots]^{\prime \prime 79}$. Biolodzy korzystają z pojęcia „cel”, np. podczas obserwacji morfogenezy, embriogenezy, biosyntezy, regeneracji ${ }^{80}$. Prawdziwym przedmiotem badań biologii jest bowiem, w przekonaniu Lenartowicza, dynamika żywego osobnika, traktowanego jako niepodzielna całośś ${ }^{81}$. Niedostrzeganie tej ukierunkowanej na cel dynamiki życia to, zdaniem polskiego filozofa, świadome lekceważenie danych empirycznych oraz pytań, które winny być spiritus movens badań przyrodniczych ${ }^{82}$.

\section{Podsumowanie}

Witalizm, ze swą dogmatyczną wiarą $\mathrm{w}$ istnienie pozamaterialnej siły obecnej w każdej formie żywej i decydującej o jej jakościowej różnicy od form nieożywionych, wiele lat temu przeszedł do historii. Rozwój nauk biologicznych zdawał się bezpowrotnie usunąć z debaty naukowej tak nienaukową, wydaje się, koncepcję życia. Jednak, po wielu latach, witalizm powrócił za sprawą polskiego filozofa, w nieco bardziej wyszukanej, uwspółcześnionej postaci. Czy ta próba wskrzeszenia dawno porzuconej doktryny odniosła sukces? W naszym przekonaniu, zdecydowanie nie. Tak naprawdę, niewielu

\footnotetext{
${ }^{77}$ Por. tamże, s. 338-339.

${ }_{78}$ Por. tamże, s. 339.

79 Tamże, s. 340.

${ }^{80}$ Por. P. Lenartowicz, Wiedza przyrodnicza - nauka - religia a spór pomiędzy monizmem i pluralizmem bytowym, [w:] Vivere et Intelligere, s. 803.

${ }^{81}$ Por. tenże, Celowość dynamiki biologicznej a bezkierunkowość w ewolucjonizmie darwinowskim, s. 340.

${ }^{82}$ Por. tamże, s. 351-352.
} 
filozofów czy biologów w ogóle zainteresowało się poglądami polskiego filozofa. Przykładowo argentyński filozof Mario Augusto Bunge w jednej ze swoich książek kwituje poglądy Lenartowicza, i to w przypisie, jednym słowem - witalista, nie kontynuując dalej tematu ${ }^{83}$. Podobnie krótko komentuje poglądy polskiego filozofa w swej książce brytyjski biolog Rupert Sheldrake: „W swej szczegółowej analizie Lenartowicz pokazał, że jeśli genotyp zostaje po prostu utożsamiony z DNA, jego pozorna wartość wyjaśniająca znika" ${ }^{84}$.

Wiele z przedstawionych w niniejszym krótkim opracowaniu tez wysuwanych przez Piotra Lenartowicza budzi, nawet wśród laików, nie-fachowców w dziedzinie biologii czy filozofii, w pełni uzasadnione, naszym zdaniem, kontrowersje. Choćby wspomnieć o twierdzeniu, że DNA nie jest genomem, czy że jeżeli utożsamiamy genom z DNA, to na nowo uciekamy się do pojęcia fenotypu, i obywamy się bez genomu. Te i tym podobne stwierdzenia sprawiły, że opracowana przez Lenartowicza nowa wersja starej, dawno już przebrzmiałej doktryny witalistycznej nie znalazła szerszego uznania ani u biologów, ani u filozofów. Mimo to należy docenić intelektualną odwagę autora w konsekwentnym podążaniu własną bardzo niepopularną drogą, z której nigdy nie zboczył ani na krok. To z pewnością budzi szacunek.

\section{Bibliografia}

Carlo W. E., Reductionism and Emergence: Mechanism and Vitalism Revisited, „Proceedings and Addresses of the American Philosophical Association" 1966, nr 40, s. 94-103.

Darowski R., Profesor Piotr Lenartowicz SJ. Biografia - filozofia - bibliografia, [w:] Vivere et Intelligere. Wybrane prace Piotra Lenartowicza SJ wydane z okazji 75-lecia jego urodzin, red. J. Koszteyn, WAM, Kraków 2009, s. 9-25.

Driesch H., Der Vitalismus als Geschichte und als Lehre, J. Barth, Leipzig 1905, s. $133-$ $-238$.

${ }^{83}$ Por. M. Mahner, M. A. Bunge, Foundations of Biophilosophy, Springer, New York 1997, s. 302. Odpowiadając, sam zainteresowany jednoznacznie, z odwagą wyznaje: „On klasyfikuje mnie jako witalistę, co jest poprawne, zgodne z rzeczywistością. [...] ja wiem, że miałem i nadal mam rację". Z. Wróblewski, Rozmowa z Piotrem Lenartowiczem SJ, s. 36.

${ }^{84}$ R. Sheldrake, Nowa biologia. Rezonans morficzny i ukryty porzadek, przeł. M. Filipczuk, Virgo, Warszawa 2013, s. 55. 
Favrholdt D., Introduction, [w:] Niels Bohr. Collected Works. Vol. 10. Complementarity beyond Physics (1928-1962), red. D. Favrholdt, Elsevier, Amsterdam 1999, s. [3] - [26].

Heller M., Lubański M., Ślaga S., Zagadnienia filozoficzne współczesnej nauki. Wstęp do filozofii przyrody, Wyd. ATK, Warszawa 1997.

Höffe O., Immanuel Kant, przeł. A. Kaniowski, PWN, Warszawa 1995.

Hull D. L., The Philosophy of Biological Science, Prentice-Hall, Englewood Cliffs, New Jersey 1974.

Jurand A., Budowa żywej materii, Wiedza Powszechna, Warszawa 1957.

Kant I., Krytyka władzy sądzenia, przeł. J. Gałecki, PWN, Warszawa 1986.

Koszteyn J., Lenartowicz P., Integracja dynamiki biologicznej a drzewa rodowodowe istot żywch, [w:] Vivere et Intelligere. Wybrane prace Piotra Lenartowicza SJ wydane z okazji 75-lecia jego urodzin, red. J. Koszteyn, WAM, Kraków 2009, s. 747-760.

Koszteyn J., Lenartowicz P., Struktura bytu żywego $w$ arystotelizmie, [w:] Vivere et Intelligere. Wybrane prace Piotra Lenartowicza SJ wydane z okazji 75-lecia jego urodzin, red. J. Koszteyn, WAM, Kraków 2009, s. 355-379.

Kunicki-Goldfinger W., Dziedzictwo i przyszłość. Rozważania nad biologia molekularną, ewolucja i człowiekiem, PWN, Warszawa 1974, s. 28.

Kunicki-Goldfinger W., Podstawy biologii. Od bakterii do człowieka, PWN, Warszawa 1980.

Lenartowicz P., Celowość dynamiki biologicznej a bezkierunkowość w ewolucjonizmie darwinowskim, [w:] Vivere et Intelligere. Wybrane prace Piotra Lenartowicza SJ wydane $z$ okazji 75-lecia jego urodzin, red. J. Koszteyn, WAM, Kraków 2009, s. 337-354.

Lenartowicz P., Mitologia programu genetycznego DNA, [w:] Vivere et Intelligere. Wybrane prace Piotra Lenartowicza SJ wydane z okazji 75-lecia jego urodzin, red. J. Koszteyn, WAM, Kraków 2009, s. 101-114.

Lenartowicz P., Pojęcie całości i przyczyny w dziejach embriologii, [w:] Vivere et Intelligere. Wybrane prace Piotra Lenartowicza SJ wydane z okazji 75-lecia jego urodzin, red. J. Koszteyn, WAM, Kraków 2009, s. 61-100.

Lenartowicz P., Sens i zakres pojęcia informacji genetycznej, [w:] Vivere et Intelligere. Wybrane prace Piotra Lenartowicza SJ wydane z okazji 75-lecia jego urodzin, red. J. Koszteyn, WAM, Kraków 2009, s. 133-144.

Lenartowicz P., Trzy koncepcje dynamiki biologicznej: arystotelesowska, neo-darwinowska, inteligentnego projektu, [w:] Vivere et Intelligere. Wybrane prace Piotra Lenartowicza SJ wydane z okazji 75-lecia jego urodzin, red. J. Koszteyn, WAM, Kraków 2009, s. 285-303.

Lenartowicz P., Wiedza przyrodnicza - nauka - religia a spór pomiędzy monizmem i pluralizmem bytowym, [w:] Vivere et Intelligere. Wybrane prace Piotra Lenarto- 
wicza SJ wydane z okazji 75-lecia jego urodzin, red. J. Koszteyn, WAM, Kraków 2009, s. 789-804.

Loeb J., Wstęp do fizjologii i psychologii porównawczej, przeł. Z. Szymanowski, Warszawa 1906.

Mahner M., Bunge M. A., Foundations of Biophilosophy, Springer, New York 1997.

Mahrburg A., Stowo wstępne, [w:] Loeb J., Wstęp do fizjologii i psychologii porównawczej, przeł. Z. Szymanowski, Warszawa 1906, s. 5-10.

Mayr E., To jest biologia. Nauka o świecie ożywionym, przeł. J. Szacki, Prószyński i S-ka, Warszawa 2002, s. 23.

Nusbaum-Hilarowicz J., Idea ewolucji w biologii: Zarys dziejów ewolucjonizmu do końca XIX wieku, Państwowe Wydawnictwo Rolnicze i Leśne, Warszawa 1952.

Nusbaum-Hilarowicz J., Szlakami wiedzy. Szkice z zagadnień biologii współczesnej, Lwów 1921.

Petrusewicz K., Mechanizm i witalizm a materializm dialektyczny, „Myśl Współczesna" 1951, nr 3/4, s. 396-426.

Ruse M, Review: A. Rosenberg, Darwinian Reductionism. Or, How to Stop Worrying and Love Molecular Biology, „The Philosophical Quarterly” 2010, nr 60, s. 204-208 .

Rutkiewicz B., Neowitalizm, „Biblioteka Warszawska” 1912, nr 1, s. 100-118.

Rutkiewicz B., Współczesny antymechanizm biologiczny i podstawy finalizmu, Lublin 1929.

Sheldrake R., Nowa biologia. Rezonans morficzny i ukryty porzadek, przeł. M. Filipczuk, Virgo, Warszawa 2013.

Wróblewski Z., Rozmowa z Piotrem Lenartowiczem SJ, [w:] Vivere et Intelligere. Wybrane prace Piotra Lenartowicza SJ wydane z okazji 75-lecia jego urodzin, red. J. Koszteyn, WAM, Kraków 2009, s. 26-58.

Zaniewski R., Teorie o pochodzeniu i rozwoju życia a naturalizm chrześcijański, Katolicki Ośrodek Wydawniczy „Veritas”, Londyn 1953.

Zięba S., Natura życia w aspekcie organizacji, „Nauka” 1998, nr 4, s. 29-56.

\section{Abstract \\ Piotr Lenartowicz's Noevitalistic Concept of Life}

Immanuel Kant, in his fundamenal work entitled Critique of Judgment of 1790, takes up the topic of relation of casual and teleological description. Some controversy between mechanicism and vitalism, which has lasted for centuries, concerns precisely this issue. Even though Kant was not a vitalist in the true sense of this word, he 
highlighted the necessity for teleological method in the description of the origin, development and function of a living organism.

Numerous Polish philosophers, including a recently deceased Jesuit, Piotr Lenartowicz, often referred in their writings to Kant's deduction on the casualitypurpose issue. In this article we are going to attempt to bring Kant's inspiration in Lenartowicz's neovitalistic concept of life.

Key words: causalism, teleology, neovitalism 